\title{
The effects of selenium and conjugated linoleic acid (CLA) isomers on fatty acid composition, CLA isomer content in tissues, and growth of rats*
}

\author{
M. Czauderna' ${ }^{1}$ J. Kowalczyk, I. Wąsowska, K. M. Niedźwiedzka \\ and B. Pastuszewska
}

\author{
The Kielanowski Institute of Animal Physiology and Nutrition, \\ Polish Academy of Sciences \\ 05-110 Jablonna, Poland
}

(Received 21 July 2003; accepted 28 October 2003)

\begin{abstract}
The effects of conjugated linoleic acid (CLA) isomers and/or selenium $\left(\mathrm{as}_{2} \mathrm{NeO}_{4}\right)$ on rat growth performance and levels of some fatty acids (FA) in femoral muscles and perigonadal fat were investigated. Feeding a mixture of CLA isomers, the trans-10,cis-12 isomer, or selenium (Se) tended to decrease the rats' body weight compared with the control animals, whereas a diet supplemented with both Se and the trans-10, cis-12 isomer produced the highest increase in body weight gain and the highest feed conversion efficiency. None of the experimental diets had any influence on brain, kidney, pancreas, or liver weight, while they significantly increased spleen mass. The administered CLA isomers significantly increased the contents of CLA isomers and non-CLA fatty acids containing conjugated double bonds (CD) in the assayed tissues. Se and individual CLA isomers or their mixture increased the CLA isomer and CD contents in muscles, while feeding only the cis-9, trans-11 isomer and Se resulted in an increase in CD and sum of all CLA isomers in fat. These results demonstrate that the trans-10,cis-12 isomer is preferentially driven through the $\beta$-oxidation pathway in muscles and fat compared with the cis-9,trans-11 isomer. CLA isomers added to Se-unsupplemented or -supplemented diets increased the levels of total FA in muscles only, while decreased the level of total assayed saturated FA in fat. Feeding Se and individual CLAs or a mixture of these isomers resulted in increasing both the sum of $c i s$-monounsaturated FA (cis-MUFA), CD and polyunsaturated FA (PUFA) in muscles, but generally resulted in decreasing the level of total saturated FA, cis-MUFA and PUFA in fat. The interaction between Se and a mixture of CLA isomers or the trans-10,cis-12 isomer most effectively protected CLA isomers from peroxidation damage and/or catabolism in muscles.
\end{abstract}

KEY WORDS: rat, CLA, isomers, conjugated dienes, selenium, body gain, feed intake

\footnotetext{
* Suported in part by the State Committee for Scientific Research, Grant No 3 PO6Z 03422

${ }^{1}$ Corresponding author: e-mail: r.czauderna@ifzz.pl
} 


\section{INTRODUCTION}

Conjugated linoleic acid (CLA) isomers (predominant isoforms: cis-9,trans-11 and trans-10,cis-12), which are mainly present in ruminant meat and milk fat (Jahreis et al., 1997; Bauman et al., 2000), are believed to play a principal role in many important physiological functions and may act to convey body composition or to modulate immune function. In ruminants or monogastric animals, the optimal content of CLA isomers is highly correlated with adiposity and overall energy expenditure. CLA isomers are also believed to inhibit tumorigenesis by interfering in the metabolism of some carcinogens. The specific CLA isomers responsible for these biological effects have not been clearly established, although the physiologically most active isomer, cis-9, trans-11, is thought to play a key role in the effect of CLAs on atherosclerosis and in their anticarcinogenic properties. Moreover, many authors found some beneficial health effects of another CLA isomer, trans-10,cis-12, on lipid metabolism such as body fat reduction with enhancement of lean body mass (Sébédio et al., 1999; Alasnier et al., 2002). Several studies give support not only to CLAs as effective antioxidants, but also to their ability to increase fatty acid oxidation. An increased hydroxybutylate:acetoacetate ratio has led some authors to postulate that the dietary trans-10,cis-12 isomer appears to exert its hypolipidemic effect by increasing $\beta$-oxidation of fatty acids at the expense of fatty acid esterification. In agreement with these results, many other recent studies have demonstrated that feeding CLAs enriched in the trans-10, cis-12 isomer is a more potent antiobesity agent in rodents compared with other CLA isomers. Several recent studies had reported an inverse relationship between CLA and blood plasma leptin in rats and mice (DeLany at al., 1999; Tsuboyama-Kasaoka et al., 2000; Rahman et al., 2001). Moreover, the trans-10, cis-12 isomer reduced excess weight gain, lowered blood lipids and improved feed efficiency. Early studies using rats found that the content of polyunsaturated fatty acids (PUFA), especially in serum cholesterol esters and phospholipids, was positively correlated with the selenium (Se) concentration in the diet (Crespo et al., 1995). Se, an essential nutritional trace element for mammals, has been found to be an integral part of the active site of cytosolic and mitochondrial glutathione peroxidases as well as phospholipid hydroperoxide glutathione peroxidase (cGPx) (Wolffram, 1999; Zagrodzki et al., 2000, 2001; Arteel and Sies, 2001). Furthermore, studies have established that phospholipid hydroperoxide cGPx acts more directly in protecting PUFA from peroxidation damage (Crespo et al., 1995).

The potential importance of CLA isomers in living organisms, as well as that of Se, essentially related to protection against oxidative stress, made it desirable to study the extent to which dietary CLA isomers may contribute to the CLA isomer levels in femoral rat muscle and perigonadal fat. The objective of the present experiment was also to investigate the effect of dietary Se (as sodium selenate) on 
some other fatty acid concentrations in these rat tissues. Moreover, the influence of the experimental factors on the body gain of rats, organ weight, and feed intake was also determined.

\section{MATERIAL AND METHODS}

\section{Animals and diets}

Ten groups of female rats (Wistar, Ifz: BOA), at 8 weeks of age, each weighing about $200 \mathrm{~g}$ at the beginning of the experiment, were housed individually in plastic cages at a constant temperature $\left(22 \pm 1^{\circ} \mathrm{C}\right)$ with $12 \mathrm{~h}$ light-dark cycle and relative humidity $50-60 \%$. Each group comprised 7-8 animals. During a 1-week preliminary period the animals were fed a standard Labofeed diet produced by the Feeds and Concentrates Production Plant in Kcynia, A. Morawski (Poland) (Pastuszewska et al., 2000) given at a submaintenance level to reduce body fat content. During that time they decreased body weight by about $15 \mathrm{~g}$ per animal. Then they were fed the experimental diets (Table 1) enriched with a CLA isomer mixture, cis-9,trans-11 isomer $(c 9, t 11)$, trans-10, cis-12 $(t 10, c 12)$ isomer or/and $\mathrm{Se}\left(\right.$ as $\left.\mathrm{Na}_{2} \mathrm{SeO}_{4}\right)$. The rations were adjusted each day to ensure the ad libitum feeding level. Feed intake and body weight of rats were measured weekly. No lesions or symptoms of Se or CLA isomer intoxication were found in rats fed the experimental diets. After the four-week experimental period the rats were killed

TABLE 1

Diet composition

\begin{tabular}{|c|c|c|}
\hline Group & Supplement & Concentration \\
\hline 1 (control) & - & - \\
\hline $2+\mathrm{Se}$ & selenium & $2 \mathrm{ppm}$ \\
\hline 3 & CLA isomer mixture $^{1}$ & $1 \%$ \\
\hline 4 & cis-9,trans-11 isomer $(c 9, t 10)$ & $1 \%$ \\
\hline 5 & trans-10, cis-12 isomer & $1 \%$ \\
\hline 6 & CLA isomer mixture & $2 \%$ \\
\hline \multirow[t]{2}{*}{$3_{+\mathrm{Se}}$} & selenium & $2 \mathrm{ppm}$ \\
\hline & CLA isomer mixture & $1 \%$ \\
\hline \multirow[t]{2}{*}{$4_{+\mathrm{Se}}$} & selenium & $2 \mathrm{ppm}$ \\
\hline & cis-9,trans-11 isomer $(c 9, t 11)$ & $1 \%$ \\
\hline \multirow[t]{2}{*}{$5_{+\mathrm{Se}}$} & selenium & $2 \mathrm{ppm}$ \\
\hline & trans-10,cis-12 isomer $(t 10, c 12)$ & $1 \%$ \\
\hline \multirow[t]{2}{*}{$6_{+\mathrm{Se}}$} & selenium & $2 \mathrm{ppm}$ \\
\hline & CLA isomer mixture & $2 \%$ \\
\hline
\end{tabular}

${ }^{1}$ concentration ratio of the cis-9,trans-11 isomer to the trans-10,cis-12 isomer in dosed CLA standard: 1.0242 (Czauderna et al., 2003) 
and the femoral muscles and perigonadal fat samples were quickly removed and weighed.

\section{Chemicals}

All reagents were of analytical grade, whereas organic solvents were HPLC grade. Acetonitrile and n-hexane (95\%) were purchased from Lab-Scan (Ireland), while dichloro-methane and acetic acid were obtained from POCh (Poland). A CLA isomer mixture, the cis-9,trans-11 and trans-10,cis-12 isomers were supplied by Larodan Fine Chemicals AB (Sweden). The purity and details of composition of the applied individual isomers and a mixture of the CLA isomers was examined in our previous study (Czauderna et al., 2003). Sodium selenate $\left(\mathrm{Na}_{2} \mathrm{SeO}_{4}\right)$ and fatty acid standards (FA) were provided by Sigma (USA).

\section{HPLC configuration and analytical method}

A Waters (Milford, MA, USA) HPLC 625LC system for fractionation of underivatized CLA isomers was used. The system comprised a 515 pump, a 712 WISP auto-sampler and a 2487 dual $\lambda$ absorbance detector. Two analytical ionexchange columns loaded with silver ions $(250 \times 4.6 \mathrm{~mm}$ Chrompac ChromSpher $5 \mu \mathrm{m}$ Lipid columns (The Netherlands)) were used in conjunction with a guard column of $10 \times 3 \mathrm{~mm}\left(\mathrm{Ag}^{+}\right.$-HPLC system I). The underivatized CLA isomers and other FA-containing conjugated double bonds (CD) in the assayed samples were determined according to Czauderna et al. (2003).

The derivatized CLA isomers and other FA in muscles and fat samples were determined according to Czauderna and Kowalczyk (2002). The HPLC system comprised two Nova Pak $\mathrm{C}_{18}$ columns $(4 \mu \mathrm{m}, 250 \times 4.6 \mathrm{~mm}$ I.D., Waters $)$, an alliance separation module (model 2690, Waters) and a Waters 996 photodiode array detector (HPLC system II).

\section{Preparation and hydrolysis of samples}

Muscles and fat samples were lyophilized and stored in sealed tubes at $-20^{\circ} \mathrm{C}$ until analysed. Muscle and fat samples (20-50 mg) were hydrolysed with $3.5 \mathrm{ml}$ of $2 \mathrm{M} \mathrm{NaOH}$ at $80-85^{\circ} \mathrm{C}$ for $30 \mathrm{~min}$ in sealed tubes. The hydrolysates were acidified with $4 \mathrm{M} \mathrm{HCl}$ and then free FA were extracted with dichloromethane (Czauderna and Kowalczyk, 2002). The lower organic layer was dried with $\mathrm{Na}_{2} \mathrm{SO}_{4}$ and then the organic solvent was removed under a stream of argon. Afterwards the residue was used for derivatization as below or re-dissolved in $1 \mathrm{ml}$ of dichloromethane and then $30 \mu \mathrm{l}$ of the resulting solution were injected onto the ion-exchange columns ( $\mathrm{Ag}^{+}$-HPLC system I) (Czauderna et al., 2003). 


\section{Derivatization procedure}

To a residue in a reacti-vial, $0.5 \mathrm{ml}$ of dibromacetophenone ( $48 \mathrm{~g} / \mathrm{L}$ in acetone) and $60 \mu \mathrm{l}$ of triethylamine were added. Next, all FA were derivatized and prepared for HPLC analyses according to Czauderna et al. (2002). The derivatized samples were injected onto $\mathrm{C}_{18}$-Nova Pak columns (HPLC system II) (Czauderna and Kowalczyk, 2002).

\section{Statistical analysis}

Statistical analyses of the effects of the CLA isomers or Se were conducted using the nonparametric Mann-Whitney $U$ test for comparing independent experimental groups, while statistical analyses of the simultaneous Se and CLA isomer treatments (Groups $3_{+\mathrm{Se}}-6_{+\mathrm{Se}}$ ) were performed applying two-factorial analysis for comparison with the independent control group 1. The Statistica (version 6) and Excel 2000 programs were used for the statistical analyses. Differences were considered statistically significant at $\mathrm{P}<0.05$ or at $\mathrm{P}<0.01$.

\section{RESULTS AND DISCUSSION}

\section{The effects of experimental diets on body mass gain and feed intake}

As can be seen from Table 2, feeding the CLA isomer mixture (Groups 3 and 6), the trans 10, cis-12 isomer (Group 5), or only Se (Group $2_{+\mathrm{Se}}$ ) to rats tended to decrease body weight gain compared with control rats (Group 1). Supplementation of the diet enriched only in the trans-10,cis-12 isomer most efficiently decreased body weight gain and feed conversion efficiency. These results are supported by several other studies, which have indicated that the trans-10,cis-12 isomer, due to its geometric and positional structure, is the most potent CLA isomer in term of antiobesity activity, thus, the one which most efficiently reduces feed intake, body weight gain, as well as increases energy expenditure. In contrast, when the cis-9, trans-11 isomer was added to the rat diet (Group 4) no change in body weight gain or feed conversion efficiency was found, whereas addition of this isomer to the diet enriched in $\mathrm{Se}$ (Group $4_{+\mathrm{Se}}$ ) reduced the negative effect of Se on body weight gain of rats (Group $2_{+\mathrm{Se}}$ ). A similar phenomenon was observed when the CLA isomer mixture was present in the diets enriched in Se (groups $3_{+\mathrm{Se}}$ and $6_{+\mathrm{Se}}$ ), moreover, the higher CLA dose (2\%) resulted in the smallest body weight gain depression in rats fed Se (Group $6_{+\mathrm{Se}}$ ). On the basis of the obtained results, it can be concluded that the interaction between Se and the CLA isomer mixture or the cis-9, trans-11 isomer reduced the negative effect of the Se-supplemented diet on rat 
TABLE 2

Feed intake, body mass gain, feed conversion efficiency in rats fed diet with CLA mixtures ( 1 and $2 \%$ ) or individual isomers (1\%) (i.e. $c 9, t 11$ or $t 10 c 12)$ without Se or with $\mathrm{Se}\left(_{+\mathrm{Se}}\right)$ diets (FCE: $\mathrm{g}$ body mass gain $/ \mathrm{g}$ feed intake $)^{1}$

\begin{tabular}{|c|c|c|c|c|c|c|}
\hline \multirow{2}{*}{ Group } & \multicolumn{3}{|c|}{ Feed intake for periods, days ${ }^{2}$} & \multirow{2}{*}{$\begin{array}{l}\text { Total feed } \\
\text { intake, } \mathrm{g}^{3}\end{array}$} & \multirow{2}{*}{$\begin{array}{c}\text { Body mass } \\
\text { gain, } g\end{array}$} & \multirow{2}{*}{$\begin{array}{r}\mathrm{FCE} \\
\mathrm{g} / \mathrm{g}\end{array}$} \\
\hline & $1-7$ & $8-14$ & $15-21$ & & & \\
\hline 1 & $125.8^{\mathrm{ABCDab}}$ & 114.7 & 100.0 & $435.3^{\mathrm{abc}}$ & $59.4^{\mathrm{a}}$ & 0.1365 \\
\hline $2_{+\mathrm{Se}}$ & $124.3^{\mathrm{c}}$ & $116.2^{\mathrm{b}}$ & 96.3 & 432.8 & $52.8^{\mathrm{b}}$ & 0.1220 \\
\hline $3^{\text {tse }}$ & $118.2^{\mathrm{Ad}}$ & $112.0^{\mathrm{a}}$ & 97.6 & $426.5^{\mathrm{a}}$ & 54.8 & 0.1285 \\
\hline 4 & $125.0^{\mathrm{d}}$ & $122.0^{\mathrm{a}}$ & 98.1 & $439.5^{\mathrm{d}}$ & 59.7 & 0.1359 \\
\hline 5 & $116.6^{\mathrm{B}}$ & 114.1 & 94.6 & 420.2 & 54.1 & 0.1287 \\
\hline 6 & $116.4^{\mathrm{C}}$ & 108.5 & 96.7 & $412.9^{\text {bd }}$ & 56.8 & 0.1376 \\
\hline $3_{+\mathrm{Se}}$ & $118.0^{\mathrm{a}}$ & 114.7 & 100.0 & $425.4^{\mathrm{d}}$ & 56.1 & 0.1319 \\
\hline $4_{+\mathrm{Se}}^{+\mathrm{Se}}$ & 123.5 & 115.7 & 97.5 & 430.4 & $55.5^{\mathrm{a}}$ & 0.1289 \\
\hline $5_{+\mathrm{Se}}$ & $120.2^{\mathrm{b}}$ & 116.1 & 99.8 & 435.8 & $62.2^{\mathrm{b}}$ & 0.1427 \\
\hline $6_{+\mathrm{Se}}$ & $113.4^{\mathrm{Dc}}$ & $109.8^{b}$ & 95.6 & $414.6^{\mathrm{cd}}$ & 58.4 & 0.1409 \\
\hline
\end{tabular}

${ }^{1}$ mean values in columns having the same superscripts are significantly different at ${ }^{\mathrm{A}, \mathrm{B}} \mathrm{P}<0.01$ or at ${ }^{\mathrm{a}, \mathrm{b}} \mathrm{P}<0.05$ level

${ }^{2}$ feed intake in 22-28 days was not included as it did not differ among a group

${ }^{3}$ during the whole experimental period (28 days)

growth performance. It was found that the trans-10, cis-12 isomer in combination with Se (Group $5_{+\mathrm{Se}}$ ) produced the highest body weight gain $(\mathrm{P}<0.05)$ as well as the best feed conversion efficiency. Therefore, it seems reasonable to assume that the interaction between Se and the trans-10,cis-12 isomer or its metabolites resulted in the most efficient elevation of body weight accretion in rats, consequently, most effectively decreased energy expenditure. Rats fed only Se-supplemented diets (Group $2_{+\mathrm{Se}}$ ) showed the most distinctly reduced body weight gain, therefore, $\mathrm{Se}$ in the diet is responsible for the lowest feed conversion efficiency.

Supplementation of the diets with the trans-10,cis-12 isomer (Group 5) significantly decreased $(\mathrm{P}<0.01)$ feed intake during the first week of the experiment (Table 2), although no significant decrease was observed after longer experimental times (2-4 weeks). The obtained results are consistent with the above-mentioned data that the trans-10, cis-12 isomer decreased the body weight gain of rats. Also, feed intake over the period of the first and second week of the study was significantly ( $\mathrm{P}<0.01$ and $\mathrm{P}<0.05$, respectively) influenced by the inclusion of the CLA isomer mixture into the diet at the lower level (1\%), but from week 3 to 4 there was only a tendency towards lower feed intake; however, total feed intake significantly decreased $(\mathrm{P}<0.05)$. Rats fed the diet containing $2 \%$ CLA (Group 6) showed a stronger effect on reducing feed intake than those receiving $1 \%$ of CLA. However, a lower body weight gain was found in rats receiving $1 \%$ of the CLA isomer mixture (Group 3) than animals fed the mixture at $2 \%$ in the diet (i.e. in 
the diet containing a higher energy level). In the presence of Se, the CLA isomer mixture ( 1 or $2 \%$ in the diet) induced a similar effect on feed intake, however, only the group receiving $2 \%$ CLA and Se (Group $6_{+\mathrm{Se}}$ ) most efficiently decreased $(\mathrm{P}<0.05)$ total feed intake. In contrast, feeding the cis-9, trans-11 isomer significantly increased $(\mathrm{P}<0.05)$ total feed intake, although it had a minute effect on the rats' body weight gain and feed conversion efficiency. The opposite phenomenon was observed in the presence of Se in the diet (Group $4_{+\mathrm{Se}}$ ), because this dietary additive resulted in lower feed intake and body gain, therefore, decreased the feed conversion efficiency.

\section{Effects of experimental diets on rat organ weight}

The supplemented diets had substantial effects on heart, pancreas, spleen, and liver weight, whereas none of the diets had any effect on kidney or brain weight (Table 3$)$. Heart weight was significantly increased $(\mathrm{P}<0.01$ or $\mathrm{P}<0.05)$ by all experimental diets and particularly $(\mathrm{P}<0.01)$ by the addition of the cis-9,trans-11 isomer or 2\% CLA to Se- unsupplemented and -supplemented diets (Groups 4, 6 and $\left.4_{+\mathrm{Se}}, 6_{+\mathrm{Se}}\right)$. The increased heart weight associated with the conjugated isomers, regardless of the presence of Se in the diets, is probably due to increased lipoprotein or protein content in this organ (West et al., 1998). The action of the trans-10,cis-12 isomer in the Se-supplemented diet on the increase of pancreas and liver weight $(\mathrm{P}<0.01)$ is likely due to lipid accumulation in these organs. In the work of West et al. (1998), it was argued that liver lipid accumulation could be explained by dietary manipulations, including body mass loss, as well as modifications of protein and fat composition. As the CLA isomers, like Se, modulated immune function, probably through cytokines (West et al., 1998), spleen weight

TABLE 3

Average body mass, and organ mass of rats after 4 weeks of the experiment ${ }^{1}$

\begin{tabular}{ccllllll}
\hline Group & Rat mass & Heart & Pancreas & Spleen & Liver & Kidneys & Brain \\
\hline 1 & 241 & $0.775^{\mathrm{ABCDabc}}$ & $0.880^{\mathrm{ABCD}}$ & $0.464^{\mathrm{Aa}}$ & $9.09^{\mathrm{AB}}$ & 1.79 & 1.76 \\
$2_{+\mathrm{Se}}$ & 238 & $0.833^{\mathrm{ad}}$ & 0.943 & $0.486^{\mathrm{b}}$ & 9.47 & 1.77 & 1.75 \\
3 & 239 & $0.856^{\mathrm{b}}$ & 0.940 & 0.490 & 9.33 & 1.77 & 1.75 \\
4 & 245 & $0.897^{\mathrm{A}}$ & 0.889 & 0.479 & 9.36 & 1.73 & 1.72 \\
5 & 238 & $0.844^{\mathrm{c}}$ & $1.006^{\mathrm{B}}$ & 0.496 & 9.48 & 1.81 & 1.74 \\
6 & 240 & $0.911^{\mathrm{B}}$ & 0.897 & 0.520 & 9.44 & 1.75 & 1.75 \\
& & & & & & & \\
$3_{+\mathrm{Se}}$ & 238 & $0.859^{\mathrm{C}}$ & $1.005^{\mathrm{A}}$ & 0.471 & 9.15 & 1.72 & 1.76 \\
$4_{+\mathrm{Se}}$ & 240 & $0.928^{\mathrm{Dd}}$ & 0.940 & $0.512^{\mathrm{a}}$ & 9.52 & 1.85 & 1.75 \\
$5_{+\mathrm{Se}}$ & 246 & $0.876^{\mathrm{E}}$ & $1.038^{\mathrm{C}}$ & $0.515^{\mathrm{Ab}}$ & $10.09^{\mathrm{A}}$ & 1.79 & 1.74 \\
$6_{+\mathrm{Se}}$ & 241 & $0.921^{\mathrm{F}}$ & $1.023^{\mathrm{D}}$ & 0.518 & $9.80^{\mathrm{B}}$ & 1.73 & 1.78 \\
\hline
\end{tabular}

${ }^{1}$ means in columns with the same letter are significantly different at ${ }^{\mathrm{A}, \mathrm{B}} \mathrm{P}<0.01$ or at ${ }^{\mathrm{a}, \mathrm{b}} \mathrm{P}<0.05$ level (derived from fresh organs mass of rats normalized to $100 \mathrm{~g}$ of rat) 
also increased in rats fed the CLA isomers. High increases of spleen weight were found in rats fed the 2\% CLA isomer mixture, regardless of the presence of Se or the trans-10,cis-12 isomer in the Se-supplemented diet. We suppose that the mixture of CLA isomers or simultaneous dosage of Se and the cis-9,trans-11 or trans-10,cis-12 isomer most efficiently stimulated the immune function of rats.

The concentration of conjugated CLA metabolites in rat femoral muscles and perigonadal fat

Detailed investigations using pre-column derivatization chromatography have demonstrated that unidentified non-CLA isomers containing conjugated double bonds (CD) in fat and muscles had retention times of $23.2 \pm 0.3,24.8 \pm 0.3,38.3 \pm 0.4$ and $40.3 \pm 0.4 \mathrm{~min}$ (Czauderna and Kowalczyk, 2002). Therefore, we suggested that these compounds contained more than two double bonds because of their shorter elution times compared with retention times of the CLA isomers. The CLA isomers eluted as six peaks and appeared at around 49-55 min of an HPLC run (Czauderna and Kowalczyk, 2002). The results of earlier studies Banni et al. (1999) and Sébédio et al. (1999) also seem to support our above assumption. Moreover, Gnädig (2002) reported that Wistar rats fed a CLA isomer mixture for one month revealed the presence of conjugated fatty acids: C18:2 (cis-6,cis-9, cis-11 C18:3 and cis-6, trans-10, cis-12 C18:3), C20:3 (cis-8,cis-11,trans-13 C20:3 and cis-8,trans-12,cis-14 C20:3) and C20:4 (cis-5,cis-8,cis-11,trans-13 C20:4 and cis-5, cis-8,trans-12,cis-14 C20:4). Recent results on this subject also reinforce the finding that CLA isomers can be metabolized in vivo into long-chain PUFA using the same pathway as linoleic acid (Gnädig, 2002; Bawa, 2003). Therefore, in the current study we could successfully investigate the effect of experimental diets on the content of the sum of CD in muscles and fat of rats (Table 4). The study showed that the level of CD in muscles and fat of control rats (Group 1) was very low, while a small insignificant increase was found in the muscle of rats fed Se (Group $2_{+\mathrm{Se}}$ ). As expected, the CLA isomer mixture or individual isomers with or without Se treatments resulted in a significant increase $(\mathrm{P}<0.01)$ in the concentration of $\mathrm{CD}$ in muscles and fat compared with the control rats (Group 1) and rats fed Se (Group $2_{+\mathrm{Se}}$ ). Interestingly, this study is unique in that the animal diets enriched in Se regardless of the presence of the CLA isomers had a major impact on the CD and CLA isomer content in muscles and fat. The addition of Se to the diets enriched in CLA isomers resulted in elevated concentrations of $\mathrm{CD}$ and a mixture of CLA isomers in muscles, moreover, the highest significant increase $(\mathrm{P}<0.01)$ in $\mathrm{CD}$ was found in rats fed diets containing the cis-9,trans-11 isomer and Se (Group $4_{+\mathrm{Se}}$ ). A possible explanation may be that Se supplementation to the experimental diets stimulated the yield of the conversion of CLA isomers into metabolites containing conjugated double bonds (CD) using the same pathway as linoleic acid. 


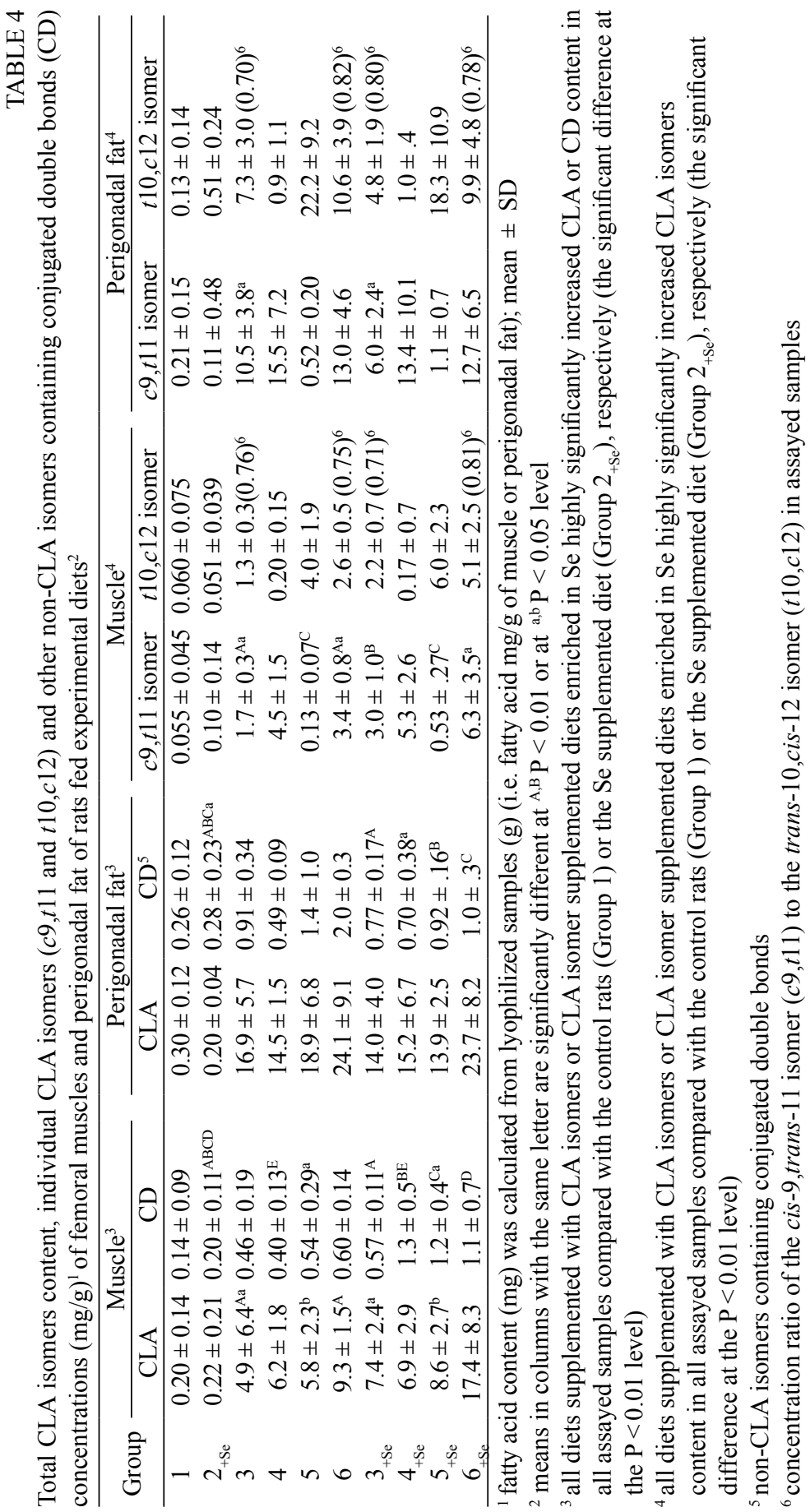


In contrast, feeding the CLA isomer mixture- or the trans-10,cis-12 isomer-enriched diets containing Se resulted in decreasing deposition of CD and the sum of all CLA isomers in rat fat. Feeding the cis-9,trans-11 isomer and Se (Group $4_{+\mathrm{Se}}$ ) to rats also resulted in an increase in the concentrations of CD and the sum of all CLA isomers in rat fat. This confirms our earlier results for rat muscles. The diet enriched with Se and the cis-9,trans-11 isomer most efficiently stimulated the formation of metabolites containing conjugated double bonds (see Group $4_{+\mathrm{Se}}$ in Table 4). More recently it was shown that the two major CLA isomers: cis-9, trans-11 and trans-10,cis-12 are substrates for $\Delta 5$ - and $\Delta 6$-desaturase as is linoleic acid (Loor and Herbein, 2003). However, considering the above results, it seems reasonable to suggest that the presence of Se and only the cis-9,trans-11 isomer in the diet most efficiently elevated the yield of the reaction of the cis-9,trans-11 isomer with $\Delta 5$ - and $\Delta 6$-desaturases, i.e. the rate-limiting enzymes determining the yield of conversion of the CLA isomers to products (CD) possessing conjugated double bonds (Group $4_{+\mathrm{Se}}$ ).

The effect of the control diet (Group 1) on the level of CLA isomers was similar to the influence of this diet on the concentration of CD in muscle and fat. The lowest contents of all CLA isomers in rat muscle were found in animals fed the control diet (Group 1), while the Se-supplemented diet (Group $2_{+\mathrm{Se}}$ ) tended to slightly increase of sum of CLA isomers and the cis-9,trans-11 isomer in rat muscle (Table 4). The increase of the dietary level of the CLA mixture induced a significant rise $(\mathrm{P}<0.01)$ of the CLA isomer content in muscle. The concentration of total CLA isomers was approximately three times greater than the cis-9,trans-11 or trans-10,cis-12 isomer. This may be because the two major CLA isomers: cis-9,trans-11 and trans-10,cis-12 isomers can be efficiently converted to other geometric or/and positional isomers of CLA. On the other hand, the total CLA isomer level in perigonadal fat is similar to the sum of the trans-10,cis-12 and cis-9,trans-11 isomers. Moreover, regardless of the presence of Se in the diets, the level of individual and total CLA isomers is considerably higher in fat compared with their concentrations in rat muscles. Therefore, we suggest that feeding individual CLA isomers or their mixture resulted in deposition of the CLA isomers in rat fat without noticeable metabolism of the CLA isomers, while the opposite effect was observed in rat muscles, indicating efficient isomerization followed by elongation and catabolism of the dietary CLA isomers.

In our investigations, the ratio of the concentrations $\left(\mathrm{R}_{\text {sample }}\right)$ of the cis-9,trans-11 isomer to the trans-10, cis-12 isomer in fat and muscles of rats fed the CLA isomer mixture (Groups 3, 6, $3_{+\mathrm{Se}}, 6_{+\mathrm{Se}}$ ) decreased compared with the concentration ratio $\left(\mathrm{R}_{\text {standard }}\right)$ of these isomers in the standard mixture of CLA isomers in the rat diets $\left(\mathrm{R}_{\text {sample }} \approx 0.8 \mathrm{vs} \mathrm{R}_{\text {standard }}=1.0242\right.$; see Tables 1 and 4$)$. Our results are in agreement with the recent study of Martin et al. (2000) who also found that the trans-10,cis-12 isomer tends to be lower than the cis-9,trans-11 isomer in rat lipids because the 
trans-10,cis-12 and trans-10,trans-12 isomers are preferentially driven through the $\beta$-oxidation pathway compared with the cis-9,trans-11 or trans-9,cis-11 isomers. An interesting finding of our study was that the response to individual isomers and to the CLA isomer mixture was higher in muscles of rats on the Sesupplemented diets compared with Se-unsupplemented treatments. These results reinforce the hypothesis that Se decreased $\beta$-oxidation of the CLA isomers in muscles. Moreover, due to the increase of the CLA isomer (substrate) concentration, the yield of conversion of isomers to long-chain PUFA containing conjugated double bonds (CD) was enhanced. This is in agreement with the results obtained in rat fat showing that Se insignificantly decreased deposition of total CLA isomers and the trans-10,cis-12 isomer in fat, while the level of the cis-9,trans-11 isomer was practically unchanged (Table 4) as the major changes in composition of deposited lipids were associated with the trans-10,cis-12 and trans-10,trans-12 isomers (Simon et al., 2000; Bell and Kennelly, 2003; Loor and Herbein, 2003).

\section{Effect of the CLA isomers and Se on fatty acid composition}

In our study, the fatty acid composition of muscles (Table 5) and fat (Table 6) was affected most by feeding CLA isomers and/or Se. Indeed, feeding both individual isomers and their mixture increased the concentration of all assayed FA in muscles compared with the control rats, though the presence of Se in the CLAisomer-enriched diets resulted in a greater increase in the concentration of all FA. A significant increase was found in the muscle of rats fed Se and $2 \%$ of the CLA isomer mixture $(\mathrm{P}<0.01)$ or the trans-10,cis-12 isomer $(\mathrm{P}<0.05)$ (i.e. Groups $6_{+\mathrm{Se}}$ and $\left.5_{+\mathrm{Se}}\right)$. A similar effect of Se in the diets was observed on the content of stearic acid and total assayed saturated fatty acids (SFA) in rat muscles (Table 5). This finding is consistent with the effect of Se on the CLA isomers in rat muscle (see Table 4) and is probably related to the inhibition of fatty acid $\beta$-oxidation in skeletal muscles. Our Se- supplemented diet (Group $2_{+\mathrm{Se}}$ ) also evaluated the quantitative significance of changes in the level of fatty acids in muscles (Table 5) and perigonadal fat (Table 6). The effect of supplementing only Se was relatively minor, however consistent. Indeed, in rat muscles and fat, supplementing only Se (VI) slightly reduced the concentration of all assayed FA, while more efficiently lowering the content of C18:0 and SFA (Group $2_{+\mathrm{Se}}$ ). Our experiment demonstrated that $\mathrm{Se}(\mathrm{VI})$, as a strong oxidant, more efficiently decreased the content of SFA than unsaturated FA. This consideration is supported by the ratios (R) of C18:0 or SFA to unsaturated FA (cis-monounsaturated FA and PUFA) because the ratio (R) generally decreased mainly due to the lower level of SFA in muscles (Table 5).

The values of the R ratios summarized in Table 6 varied inconsistently because their values depend upon material changes in the levels of both saturated and unsaturated FA. The diets enriched in individual CLA isomers or their mixture 


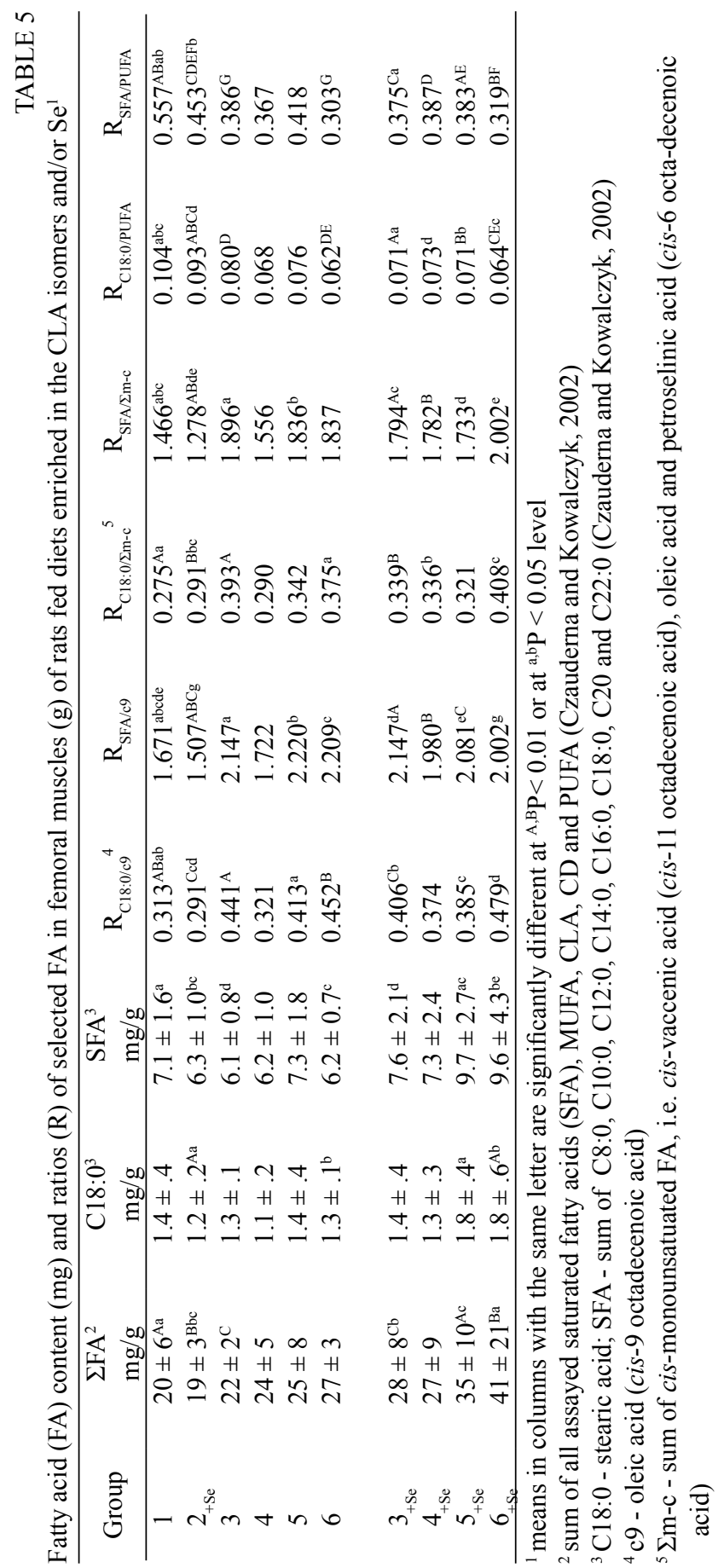


0
里
$\frac{1}{6}$

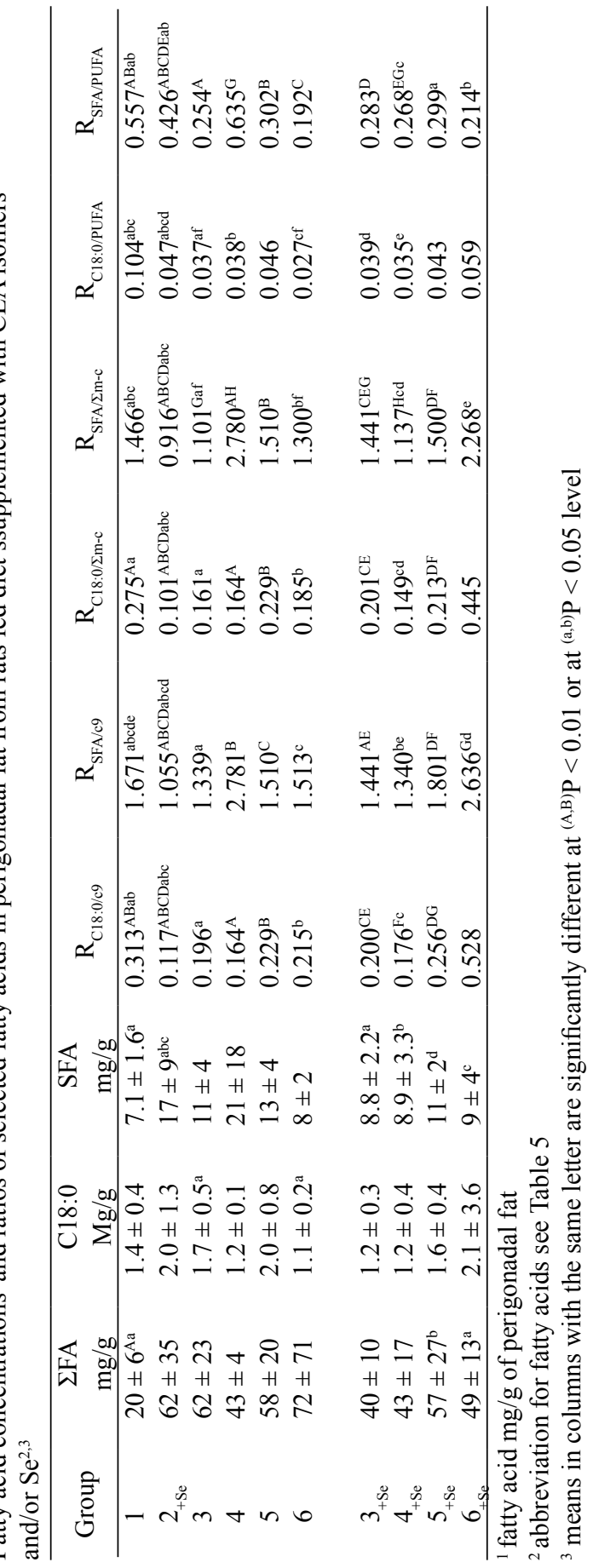


generally increased the ratios of C18:0 or SFA to oleic acid and to the sum of cismonounsaturated FA (cis-MUFA) in muscles and fat, while decreasing the ratios of C18:0 or SFA to PUFA (i.e. non-conjugated PUFA). Considering the results summarized in Tables 5 and 6, we suggest that individual isomers (probably especially the trans-10, cis-12 isomer) or a mixture of CLA isomers in the experimental diets caused a reduction in $\Delta 9$-desaturase capacity, inhibited steaoryl-CoA desaturase mRNA expression and fatty acid synthase (Simon et al., 2000; Loor and Herbein, 2003), so the muscle and fat concentrations of both oleic acid and sum the of cis-MUFA decreased. The obtained results fully confirmed our above suggestion as higher values of the ratio $(\mathrm{R})$ of $\mathrm{C} 18: 0$ to oleic acid were observed in muscles (Table 5) and fat (Table 6) of rats fed the trans-10,cis-12 isomer (Group 5) compared with the cis-9,trans-11 isomer (Group 4).

The diets supplemented with individual CLA isomers or their mixture had a synergetic effect on PUFA accretion in muscles, while practically not affecting the level of deposited PUFA in perigonadal fat. In our study, CLA isomer treatment generally resulted in a considerable decrease in the concentrations of SFA in fat, whereas minor insignificant reductions were observed in rat muscles.

Feeding Se and individual CLA isomers or their mixture resulted in increasing the sum of both cis-MUFA and PUFA in muscles (Table 5) compared with the control rats (Group 1) and/or rats fed the CLA isomers (Groups 3, 4, 5 and 6). Therefore, considering all presented results it seems likely that the diets enriched in Se and individual CLA isomers or their mixture stimulated lipogenesis, desaturation and elongation as well as inhibited FA $\beta$-oxidation in muscles. On the other hand, Se in the diets enriched in individual or mixtures of CLA isomers generally resulted in decreasing both the level of total assayed SFA, oleic acid, cis-MUFA and PUFA in perigonadal fat (Table 6) compared with the control rats (Group 1) and/or rats fed only the CLA isomers (Groups 3, 4, 5 and 6). Consequently, the changes of ratios $(\mathrm{R})$ are not consistent, however, generally, increased for values of $\mathrm{R}_{\mathrm{C} 18: 0 / 9 \mathrm{c}}, \mathrm{R}_{\mathrm{SFA} / \mathrm{c} 9}, \mathrm{R}_{\mathrm{C} 18: 0 / \mathrm{\Sigma m}-\mathrm{c}}$ and $\mathrm{R}_{\mathrm{SFA} / \mathrm{m}-\mathrm{c}}$, while decreased for $\mathrm{R}_{\mathrm{C} 18: 0 / \mathrm{PUFA}}$ and $\mathrm{R}_{\text {SFAPUFA }}$. Therefore, we could hypothesize that in perigonadal fat, the diets supplemented with Se and individual CLA isomers or their mixture enhanced lipolysis at the expense of FA esterification and reduced the activities of $\Delta 9-, \Delta 6$ - and/or $\Delta 5$-desaturases.

\section{CONCLUSIONS}

The present study demonstrated that the trans-10,cis-12 and the CLA isomer mixture induced a decrease in body weight gain and food intake, while the cis-9, trans-11 isomer did not change body mass accretion or food intake. The cis-9, trans-11 isomer is the most potent CLA isomer possessing anticarcinogenic pro- 
perties, while feeding this isomer had no effect on lipid-metabolizing enzymes in any of the organs or tissues of rats. The cis-9,trans-11 isomer showed a minor role in mediating many of the biochemical effects attributed to the trans-10,cis-12 isomer. A 12-double bond appears to be a key structure for inhibiting stearoylCoA desaturase activity, especially when coupled with a 10-double bond, but not with a 9-double bond (Alasnier et al., 2002). Due to the geometric and positional structure, the trans-10,cis-12 isomer is a more potent antiobesity agent in mammals. This isomer increased FA $\beta$-oxidation at the expense of FA esterification, increased hepatic and adipose carnitine palmitoyl-CoA transferase activity, reduced excess body gain, increased energy expenditure, increased feed efficiency and lipolysis (West at al., 1998; Alasnier et al., 2002). Both main isoforms of a mixture of CLA isomers can reduce circulating leptin levels (by decreasing leptin gene expression), therefore, this decrease resulted in reducing the adiposity and body weight of the examined animals (Rahman et al., 2001; Corino et al., 2002).

Based on the above observations, we suggest that simultaneous dietary supplementation of Se and the trans-10,cis-12 isomer or the CLA isomer mixture had a beneficial effect on accumulation of the trans-10,cis-12 isomer and the CLA isomer mixture in muscles. We suggest that the interaction between Se and a mixture of CLA isomers or the trans-10, cis-12 isomer most effectively protected CLA isomers from peroxidation damage and/or catabolism in muscles. The finding that Se and individual CLA isomers or their mixtures fed to animals increased the level of CLA isomers, CD, cis-MUFA and PUFA in the muscles of rats is valuable for nutritionists in the context of research to improve the nutritional quality of food for human health.

\section{REFERENCES}

Arteel G.E., Sies H., 2001. The biochemistry of selenium and gluthatione system. Environ. Toxicol. Pharmacol. 10, 153-158

Alasnier C., Berdeaux O., Chardigny J.M., Sébédio J.L., 2002. Fatty acid composition and conjugated linoleic acid content of different tissues in rats fed individual conjugated linoleic acid isomers given as triacylglycerols. J. Nutr. Biochem. 13, 337-345

Bauman D.E., Baumgard L.H., Corl B.A., Griinari J.M., 2000. Biosynthesis of conjugated linoleic acid in ruminants. Proc. Amer. Soc. Anim. Sci. 1999, 1-15 (online publication)

Bawa S., 2003. An update on the beneficial roles of conjugated linoleic acid (CLA) in modulating human health: mechanisms of action - a review. Pol. J. Food Nutr. Sci. 12, 3-13

Bell J.A., Kennelly J.J., 2003. Postruminal infusion of conjugated linoleic acids negatively impacts milk synthesis in Holstein cows. J. Dairy Sci. 86, 1321-1324

Corino C., Mourou J., Magni S., Pastorelli G., Rosi F., 2002. Influence of dietary conjugated linoleic acid on growth, meat quality, lipogenesis, plasma leptin and physiological variables of lipid metabolism in rabbits. J. Anim. Sci. 80, 1020-1028 
Crespo A.M., Reis M.A., Lanca M.J., 1995. Effect of selenium supplementation on polyunsaturated fatty acids in rats. Biol. Tr. Elem. Res. 47, 335-341

Czauderna M., Kowalczyk J., 2002. HPLC sepatration of some unsaturated and saturated fatty acids. Chem. Anal. (Warsaw) 47, 867-882

Czauderna M., Kowalczyk J., Wąsowska I., Niedźwiedzka K.M., 2002. A highly efficient method for derivatization of fatty acids for high performance liquid chromatography. J. Anim. Feed Sci. 11, 517-526

Czauderna M., Kowalczyk J., Wąsowska I., Niedźwiedzka K.M., 2003. Determination of conjugated linoleic acid isomers by liquid chromatography and photodiode array detection. J. Anim. Feed Sci. 12, 269-382

DeLany J.P., Blohm F., Truett A.A., Scimeca J.A., West D.B., 1999. Conjugated linoleic acid rapidly reduces body fat content in mice without affecting energy intake. Amer. J. Physiol. 276, R1172-R1179

Evans M.E., Brown J.M., McIntosh M.K., 2002. Isomer-specific effects of conjugated linoleic acid (CLA) on adiposity and lipid metabolism. J. Nutr. Biochem. 13, 508-516

Gnäding S., 2002. Conjugated linoleic acid (CLA): effect of processing on CLA in cheese and the impact of CLA on the arachidonic acid metabolism. PhD Dissertation, Universität Hamburg. INRA, Unité de Nutrition Lipique, Dijon (France)

Gnäding S., Rickert R., Sébédio J.L., Steinhart H., 2001. Conjugated linoleic acid (CLA): physiological effects and production. Eur. J. Lipid Sci. Tech. 103, 56-61

Jahreis G., Fritsche J., Steinhart H., 1997. Conjugated linoleic acid in milk fat: high variation depending on production system. Nutr. Res. 17, 1479-1484

Lawson R.E., Moss A.R., Givens D.I., 2001. The role of dairy products in supplying conjugated linoleic acid to man's died: a review. Nutr. Res. Rev. 14, 153-172

Loor J.J., Herbein J.H., 2003. Reduced fatty acid synthesis and desaturation due to exogenous trans 10, cis12-CLA in cows fed oleic or linoleic oil. J. Dairy Sci. 86, 1354-1369

Martin J.C., Gregoire S., Siess M.H., Genty M., Chardigny J.M ., Berdeaux O., Juaneda P., Sebedio J.L., 2000. Effects of conjugated linoleic acid isomers on lipid metabolizing enzymes in male rats. Lipids 35, 91-98

Pastuszewska B., Ochtabińska A., Morawski A., 2000. A note on the nutritional adequacy of stock diets for laboratory rats and mice. J. Anim. Feed Sci. 9, 533-542

Rahman S.M., Wang Y.M., Yotsumoto H., Cha J.Y., Han S.Y., Inoue S., Yanagita T., 2001. Effects of conjugated linoleic acid on serum leptin concentration, body-fat accumulation, and $\beta$-oxidation of fatty acid in OLETF rats. Nutrition 17, 385-390

Simon O., Männer K., Schäfer K., Sagredos A., Eder K., 2000. Effects of conjugated linoleic acids on protein to fat proportions, fatty acids, and plasma lipids in broilers. Eur. J. Lipid Sci. Tech. $102,402-410$

Sébédio J.L, Gnäding S., Chardigny J.M., 1999. Recent advances in conjugated linoleic acid research. Curr. Opin. Clin. Nutr. Metabol. Care 2, 499-506

Szymczyk B., Pisulewski P., Szczurek W., Hanczakowski P., 2000. The effects of feeding conjugated linoleic acid (CLA) on rat growth performance, serum lipoproteins and subsequent lipid composition of selected rat tissues. J. Sci. Food Agr. 80, 1553-1558

Tsuboyama-Kasaoka N., Takahashi M., Tanemura K., Kim H.J., Tange T., Okuyama H., Kasai M., Ikemoto S., Ezaki O., 2000. Conjugated linoleic acid supplementation reduces adipose tissue by apoptosis and develops lipodystrophy in mice. Diabetes 49, 1534-1542

West D.B., DeLany J.P., Camet P.M., Blohm F., Truett A.A., Scimeca J., 1998. Effects of conjugated linoleic acid on body fat and energy metabolism in the mouse. Amer. J. Physiol. 275, R667-R672 
Wolffram S., 1999. Absorption and metabolism of selenium: differences between inorganic and organic sources. In: T.P. Lyons, K.A. Jacques (Editors). Biotechnology in the Feed Industry. Nottingham University Press, pp. 547-566

Zagrodzki P., Bik D., Fitak B.A., Suchocki P., Niemczuk K., 2000. Selenoenzymes in animal tissues after supplementation with selol. Bull. Vet. Inst. Pulawy 44, 215-220

Zagrodzki P., Nicol F., Arthur J.R., Slowiaczek M., 2001. Selenoproteins in human thyroid tissues. Biofactors 14, 223-227

\section{STRESZCZENIE}

\section{Wpływ selenu i izomerów sprzężonego kwasu linolowego (CLA) w diecie na zawartość kwasów thuszczowych i izomerów CLA w tkankach szczurów oraz na ich wzrost}

Badano wpływ izomerów sprzężonego kwasu linolowego (CLA) lub/i selenu (w postaci $\mathrm{Na}_{2} \mathrm{SeO}_{4}$ ) na wzrost szczurów i poziom wybranych kwasów thuszczowych (KT) w mięśniu udowym oraz thuszczu okołogonadowym. Podawanie zwierzętom mieszaniny izomerów CLA, izomeru trans-10,cis-12 lub selenu (Se) powoduje zmniejszenie przyrostu masy ciała szczurów w porównaniu z grupą kontrolną. Przy jednoczesnym dodatku izomeru trans-10,cis-12 i Se do dawki przyrosty masy ciała zwierząt były najwyższe, a wykorzystanie paszy najlepsze. Dodatek izomerów CLA i/lub Se do diety nie miał wpływu na masę mózgu i nerek, natomiast zwiększał masę trzustki, wątroby i śledziony. Izomery CLA dodane do dawki istotnie zwiększyły w badanych tkankach stężenie izomerów CLA i innych kwasów tłuszczowych zawierających sprzężone podwójne wiązania (CD). Jednoczesne podanie Se i izomerów CLA stymuluje gromadzenie się izomerów CLA i CD w mięśniach, natomiast podawanie jedynie izomeru cis-9,trans-11 i Se stymulowało akumulację izomerów CLA i CD w tłuszczu. Badania dowiodły, że izomer trans-10,cis-12 wydajniej ulega $\beta$-oksydacji w porównaniu z izomerem cis-9,trans-11. Izomery CLA bez względu na obecność Se w dawce zwiększają zawartość KT w mięśniach, natomiast zmniejszają zawartość nasyconych KT w thuszczu. Jednoczesne podawanie Se i izomerów CLA zwiększa stężenie cis-mononienasyconych KT (cis-MNKT), CD i wielonienasyconych KT (WNKT) w mięśniu, natomiast zmniejsza zawartość nasyconych KT, cis-MNKT i WNKT w thuszczu. Jednoczesne podanie Se i mieszaniny CLA izomerów lub izomeru trans-10,cis-12 najefektywniej chroni izomery CLA przed oksydacyjnym uszkodzeniem oraz hamuje ich katabolizm. 